Journal of Chromatography, 305 (1984) 363-371

Biomedical Applications

Elsevier Science Publishers B.V., Amsterdam - Printed in The Netherlands

CHROMBIO. 1929

\title{
HIGH-PERFORMANCE LIQUID CHROMATOGRAPHIC ANALYSIS OF CEFOTETAN EPIMERS IN HUMAN PLASMA AND URINE
}

F, KEES and H. GROBECKER*

Department of Pharmacology, University of Regensburg, Universitätstrasse 31, D-8400 Regensburg (F.R.G.)

and

K.G. NABER

Urologic Clinic, Elisabeth Hospital, Schulgasse 20, D-8440 Straubing (F.R.G.)

(First received July 19th, 1983; revised manuscript received August 31st, 1983)

\section{SUMMARY}

Cefotetan, a new broad-spectrum $7 \alpha$-methoxycephalosporin antibiotic, was assayed in plasma and urine by means of reversed-phase high-performance liquid chromatography. Commercially available cefotetan exists in two epimeric forms. The procedure described allows the separation and quantitation of both. epimers. For the first time a different pharmacokinetic behaviour ( $t_{1 / 2}=3 \mathrm{~h}$ versus $4 \mathrm{~h}$ ) for each epimer after intravenous injection to healthy volunteers is demonstrated. It is assumed that one epimer is bound to a greater extent to serum proteins and is therefore responsible for the differences observed. As both epimers exhibit similar antibacterial activity, it seems doubtful whether these differences would have clinical significance. Iothalamic acid was determined simultaneously as a marker of kidney function.

\section{INTRODUCTION}

Cefotetan disodium is a new $7 \alpha$-methoxycephalosporin with a wide spectrum of antibacterial activity and remarkable stability against various $\beta$-lactamases. Pharmacokinetic parameters in man have been studied in different races [1-4]. The commercially available product consists of a mixture of two epimers because of the asymmetric carbon atom at the dithietan ring. In this paper the $R$ and $S$ epimers are called A and B, respectively, because the absolute configuration was not known. In weakly alkaline media the two epimers are 


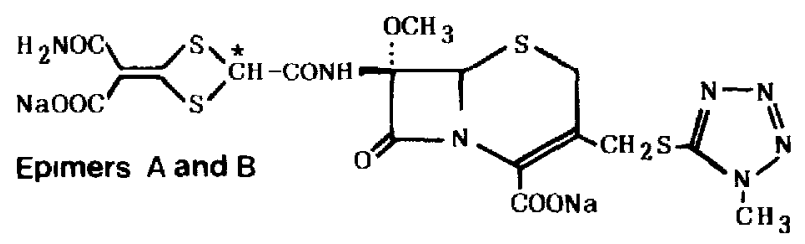

$$
p H<8 \| p H>8
$$

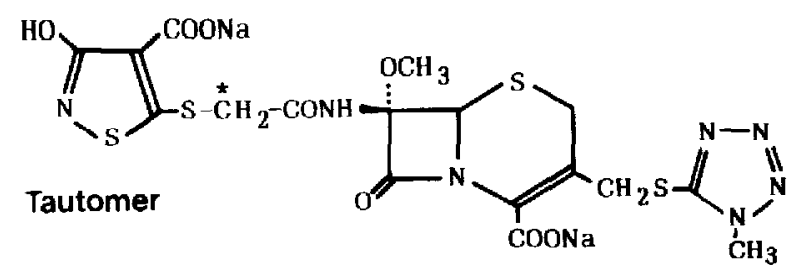

Fig. 1. Chemical structure of cefotetan. The asterisk marks the epimeric centre and the position of this carbon atom in the tautomer.

in equilibrium with a third tautomeric form (Fig. 1). Under physiological conditions the proportion of the tautomer is small, as demonstrated by others [ 1 , 4]. The aim of the present study was to elucidate the pharmacokinetic behaviour of both epimers of cefotetan after intravenous injection of the drug in healthy volunteers.

\section{MATERIALS AND METHODS}

\section{Reagents}

Cefotetan was provided by ICI-Pharma (Plankstadt, F.R.G.), Conray $70^{\circledR}$ (meglumine iothalamate) and iothalamic acid \{3-(acetylamino)-2,4,6-triiodo-5[(methylamino)carbonyl]-benzoic acid\} by Byk-Gulden (Konstanz, F.R.G.); acetonitrile and dichloromethane (Chrom AR) were obtained from Promochem (Wesel, F.R.G.), the primary and secondary sodium phosphates (analytical grade) from Merck (Darmstadt, F.R.G.), and tetrabutylammonium bromide (purum) from Fluka (Neu-Ulm, F.R.G.). Water was purified with a Milli-Q water purification system (Millipore, Neu-Isenburg, F.R.G.).

The stock solutions of cefotetan and iothalamic acid were prepared in $\mathbf{5 0}$ $\mathrm{m} M$ sodium phosphate buffer ( $\mathrm{pH} 6.2$ ) to yield final concentrations of 1.0 $\mathrm{mg} / \mathrm{ml}$ and $10.0 \mathrm{mg} / \mathrm{ml}$, and stored in aliquots at $-20^{\circ} \mathrm{C}$. The stock solutions were then diluted with drug-free plasma to provide assay standards over a concentration range of $1.25-100 \mu \mathrm{g} / \mathrm{ml}$ for cefotetan and $12.5-1000 \mu \mathrm{g} / \mathrm{ml}$ for iothalamic acid. For urine samples the standard solutions were prepared in $50 \mathrm{mM}$ phosphate buffer (pH 6.2).

\section{Analysis of plasma and urine samples}

A 200- $\mu \mathrm{l}$ volume of plasma was buffered with $200 \mu \mathrm{l}$ of $0.1 \mathrm{M}$ sodium dihydrogen phosphate and mixed for 5 sec with $400 \mu \mathrm{l}$ of acetonitrile on a Reax 1 shaker (Heidolph, Kelheim, F.R.G.). After $15 \mathrm{~min}$ at $4^{\circ} \mathrm{C}$ the mixture was 
centrifuged $(1 \mathrm{~min}, 10,500 \mathrm{~g})$ and the clear supernatant transferred to a $12 \times$ $75 \mathrm{~mm}$ disposable polypropylene tube. Then $2.0 \mathrm{ml}$ of dichloromethane were added, the tube was capped and mixed ( $5 \mathrm{~min}$ ) on a Reax 2 Mixer (Heidolph). After centrifugation $(10 \mathrm{~min}, 4800 \mathrm{~g})$ an aliquot $(5-50 \mu \mathrm{l})$ of the upper aqueous phase was injected onto the column.

Urine samples were centrifuged $(10 \mathrm{~min}, 4800 \mathrm{~g})$ and diluted 1:10 with $50 \mathrm{mM}$ sodium dihydrogen phosphate (resulting $\mathrm{pH} 5.8-5.9$ ).

All biological samples were stored at $-70^{\circ} \mathrm{C}$ until required for analysis.

\section{Chromatography}

The chromatographic system consisted of a pump M 6000A, a fixed-wavelength detector M 440 allowing simultaneous measurement at 254 and $280 \mathrm{~nm}$, an automatic injector WISP $710 \mathrm{~B}$, a data module $\mathrm{M} 730$ and a system controller M 720 (all from Waters Assoc., Königstein/Ts., F.R.G.). A Hibar ${ }^{\text {(a) }}$ stainless-steel column $(125 \times 4 \mathrm{~mm}$ I.D. $)$, prepacked with $5-\mu \mathrm{m}$ LiChrosorb RP18 silica (Merck), was used for separation. The flow-rate was maintained at $1.0 \mathrm{ml} / \mathrm{min}$, the resulting back-pressure was $110-115$ bar. The eluent was monitored at 254 and $280 \mathrm{~nm}$, integrating the peak area of the signals at 280 $\mathrm{nm}$. For plasma samples the mobile phase was prepared by combining $925 \mathrm{ml}$ of water, $75 \mathrm{ml}$ of acetonitrile, $5.50 \mathrm{~g}$ of sodium dihydrogen phosphate monohydrate, $1.80 \mathrm{~g}$ of disodium hydrogen phosphate dihydrate and $20 \mathrm{mg}$ of tetrabutylammonium bromide. For urine samples the contents of acetonitrile and tetrabutylammonium bromide were changed to $45-50 \mathrm{ml} / \mathrm{l}$ and $22.5 \mathrm{mg} / \mathrm{l}$, respectively. The apparent $\mathrm{pH}$ of the buffered solutions was about 6.4.

\section{RESULTS}

\section{Sample clean-up}

The major disadvantage of high-performance liquid chromatography (HPLC) in comparison with the microbiological assay is the need to remove proteins from the samples before injection onto the analytical column. In order to maintain the precision, a minimal number of clean-up steps (e.g. pipetting or extracting) is desirable. Deproteinization is usually performed by adding organic solvents or acids. Ultrafiltration seems to be a very fast and simple technique and was used for the determination of cefmenoxime in plasma; but addition of sodium dodecylsulphate (SDS), a highly protein-bound displacing agent, is necessary to recover the protein-bound fraction of the drug [5]. By adding $0.5 \%$ SDS we obtained nearly quantitative recoveries of both epimers of cefotetan from plasma using the sample clean-up procedure described under Materials and methods. However, the ion-pairing properties of SDS in reversedphase HPLC caused chromatographic aberrations with peak splitting. Deproteinization by addition of perchloric acid resulted in low recoveries because of apparent co-precipitation of cefotetan. After sample clean-up by extraction of the cephalosporin and iothalamic acid into chloroform-pentanol as described in ref. 6 , we obtained $90 \%$ recovery for both epimers of cefotetan and $70 \%$ recovery for iothalamic acid. Because of its simplicity for routine use, we preferred the procedure described under Materials and methods which is a 
modification of other methods known from the literature [7-9]. Acetonitrile acts as an efficient protein precipitation agent. In the following extraction step with dichloromethane, neutral lipophilic substances as well as the acetonitrile used for protein precipitation, are removed. The cephalosporin remains in the undiluted aqueous layer. Using this procedure we achieved quantitative recoveries from biological fluids for the following acid compounds: cefadroxil, cefotaxime, desacetylcefotaxime, cefotiam, cefmenoxime, cefsulodin, ceftazidime and iothalamic acid. For cefotetan the recovery was $85 \%$ for epimer A and $98 \%$ for epimer B. On the other hand, the recovery for a neutral compound, namely desacetylcefotaxime lactone, was only $10 \%$.

\section{Chromatography}

In Fig. 2 the chromatograms of an aqueous standard and plasma samples after simultaneous intravenous injection of $1 \mathrm{~g}$ of cefotetan and $20 \mathrm{ml}$ of Conray 70 (containing $13.2 \mathrm{~g}$ of iothalamic acid) are depicted. The best compromise between run-time and separation of the isomers of cefotetan from each other and from endogenous compounds was obtained by adding small quantities $(0.1 \mathrm{mM})$ of tetrabutylammonium salt to the buffered ( $\mathrm{pH} 6.3-6.5)$ mixture of water and acetonitrile. For urine samples it was necessary to lower
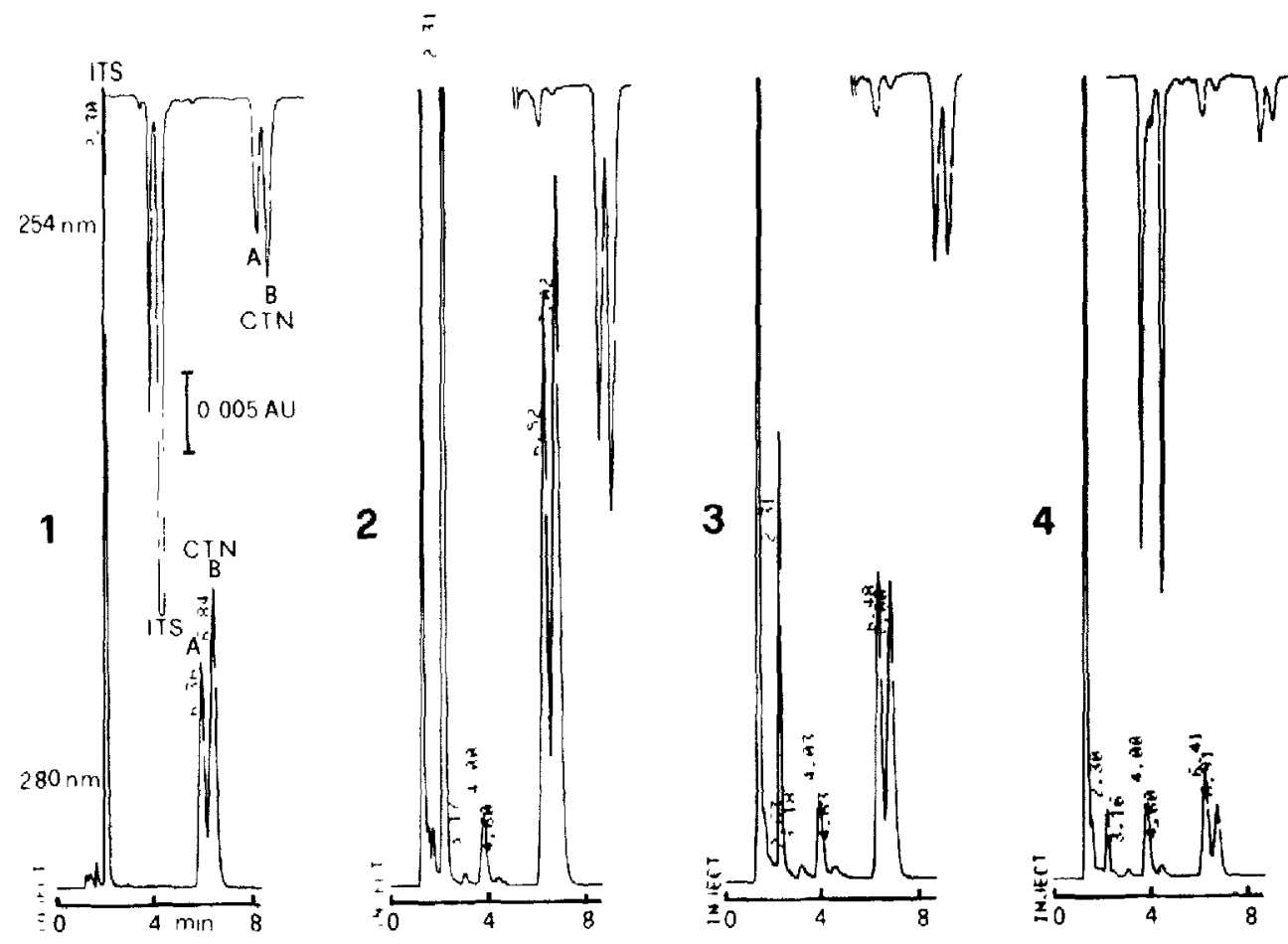

Fig. 2. Chromatograms of (1) an aqueous standard solution of cefotetan (CTN, commercially available mixture of epimers $A$ and $B$ ) and iothalamic acid (ITS) (amount injected: ITS, $5 \mu \mathrm{g}$ : CTN, $500 \mathrm{ng}$ ) and of plasma samples from a healthy volunteer $10 \mathrm{~min}(2), 2 \mathrm{~h}(3)$ and $6 \mathrm{~h} \mathrm{(4)}$ after simultaneous intravenous injection of $1 \mathrm{~g}$ of cefotetan and $20 \mathrm{ml}$ of Conray 70 (corresponding to $13.2 \mathrm{~g}$ of iothalamic acid). Concentrations $(\mu \mathrm{g} / \mathrm{ml})$ : (2) ITS, 849 ; CTN-A, 56.4; CTN-B, 72.8. (3) ITS, 204; CTN-A, 29.5; CTN-B, 29.9. (4) ITS, 27.8; CTN-A, $10.2 ;$ CTN-B, 7.3 . 


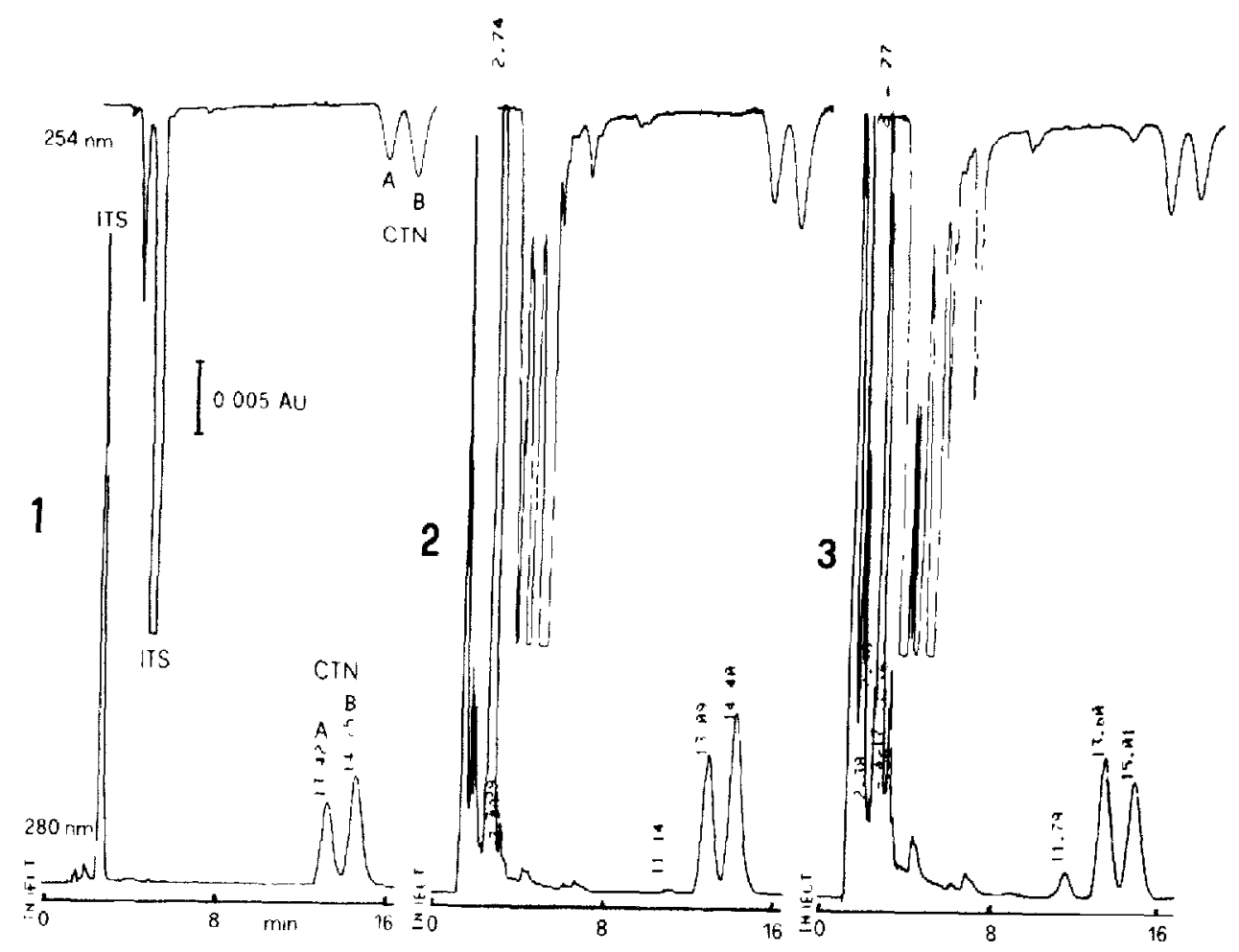

Fig. 3. Chromatograms of (1) an aqueous standard solution of cefotetan (CTN) and iothalamic acid (ITS) (amount injected: ITS, $5 \mu \mathrm{g} ;$ CTN, $500 \mathrm{ng}$ ) and of urine samples from a healthy volunteer $0-2 \mathrm{~h} \mathrm{(2)}$ and $4-6 \mathrm{~h} \mathrm{(3)}$ after simultaneous intravenous injection of $1 \mathrm{~g}$ of cefotetan and $20 \mathrm{ml}$ of Conray 70 (corresponding to $13.2 \mathrm{~g}$ of iothalamic acid). Concentrations $(\mu \mathrm{g} / \mathrm{ml}):(2)$ ITS, 9870; CTN-A, 325; CTN-B, 502. (3) ITS, 2370; CTN-A, 376 ; CTN-B, 342.

the acetonitrile content and to change the concentration of the ion-pairing agent in order to maintain the separation from interfering compounds. As a consequence the overall run-time increased to $15 \mathrm{~min}$ compared to $8 \mathrm{~min}$ for plasma samples (Fig. 3).

\section{Recovery and sensitwity}

The recoveries of iothalamic acid and cefotetan were checked in the concentration range $12.5^{-}-1000 \mu \mathrm{g} / \mathrm{ml}$ and $1.25-100 \mu \mathrm{g} / \mathrm{ml}$, respectively. Two sets of spiked plasma samples were prepared and each analysed two times on different days. The peak areas found were compared with those of standard aqueous solutions. The results are shown in Table I. The mean recoveries were $100.3 \pm 2.4 \%$ for iothalamic acid, $84.6 \pm 2.2 \%$ for isomer $\mathrm{A}$ of cefotetan and $97.6 \pm 2.4 \%$ for isomer $\mathrm{B}$. The recovenes from aqueous samples were $95.1 \pm$ $2.0 \%, 93.7 \pm 3.2 \%$ and $93.6 \pm 3.7 \%$, respectively. Obviously, the recovery of isomer A from plasma was substantially lower than the recoveries of the other two compounds. The recoveries of the individual spiked plasma samples fluctuated between 74 and $118 \%$. For quantitation of the concentrations found in the unknown plasma samples, the mean value was used. The regression lines

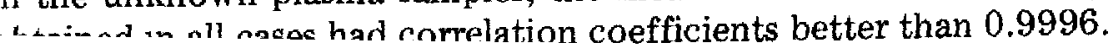




\section{TABLE I}

RECOVERY OF IOTHALAMIC ACID AND CEFOTETAN (EPIMERS A AND B) FROM HUMAN PLASMA

\begin{tabular}{|c|c|c|c|}
\hline \multirow{3}{*}{$\begin{array}{l}\text { Amount added } \\
(\mu \mathrm{g} / \mathrm{ml}) \\
\text { ITS/CTN }\end{array}$} & \multicolumn{3}{|c|}{ Recovery $^{\star}(\%)$} \\
\hline & \multirow{2}{*}{$\begin{array}{l}\text { Iothalamic } \\
\text { acid } \\
\text { (ITS) }\end{array}$} & \multicolumn{2}{|c|}{ Cefotetan (CTN) } \\
\hline & & Epimer A & Epimer B \\
\hline $1000 / 100$ & $100.7 \pm 4.9$ & $86.4 \pm 1.1$ & $97.4 \pm 3.3$ \\
\hline $500 / 50$ & $102.8 \pm 3.8$ & $87.0 \pm 2.6$ & $98.3 \pm 1.6$ \\
\hline $250 / 25$ & $101.7 \pm 3.3$ & $84.7 \pm 2.6$ & $97.0 \pm 0.8$ \\
\hline $100 / 10$ & $100.1 \pm 3.9$ & $85.5 \pm 7.3$ & $96.7 \pm 4.3$ \\
\hline $50 / 5$ & $102.2 \pm 7.9$ & $83.6 \pm 5.1$ & $102.5 \pm 10.6$ \\
\hline $25 / 2.5$ & $98.8 \pm 3.8$ & $80.4 \pm 6.6$ & $947 \pm 1.5$ \\
\hline $12.5 / 1.25$ & $95.9 \pm 97$ & $84.4 \pm 11.3$ & $96.6 \pm 124$ \\
\hline Mean \pm S.D. & $100.3 \pm 2.4$ & $84.6 \pm 2.2$ & $976 \pm 2.4$ \\
\hline
\end{tabular}

*Mean \pm S.D.; $n=4$.

is low at $280 \mathrm{~nm}\left(\lambda_{\max }=240 \mathrm{~nm}\right.$; see also Figs. 2 and 3$)$. For an injection volume of $50 \mu \mathrm{l}$ this would correspond to a limit of detection of $20-40 \mathrm{ng} / \mathrm{ml}$ and $200-400 \mathrm{ng} / \mathrm{ml}$, respectively. This analytical limit of detection could not be reached in biological fluids. In all plasma samples interfering compounds corresponding to up to $1 \mu \mathrm{g} / \mathrm{ml}$ of iothalamic acid were present, whereas in a few samples only an interfering peak corresponding to not more than $0.2 \mu \mathrm{g} / \mathrm{ml}$ of epimer B of cefotetan occurred. The blanks observed in urine were about ten tımes higher. Since up to $12 \mathrm{~h}$ after administration the concentrations of iothalamic acid were much higher than the blank values, no attempt was made to eliminate the unusually high blank value.

\section{Sample stability}

Especially if automatic injection systems are used for overnight runs, samples must be stable at room temperature $\beta$-Lactam antibiotics are labile in weak basic and strong acid media. The $\mathrm{pH}$ of plasma samples kept at room temperature rises to $9[10]$. Therefore plasma samples containing cephalosporins should be buffered to a neutral or weak acid pH [5]. Following the preparation procedure described in this report, no degradation of cefotetan or iothalamic acid was measurable within $12 \mathrm{~h}$. Moreover, at the resulting $\mathrm{pH}$ of $5.8-6.0$ the ratio of the two epimers of cefotetan was constant too, whereas in unbuffered plasma samples (final $\mathrm{pH}$ 8.2-8.3 after sample clean-up) the amount of $\mathrm{A}$ increased and that of $\mathrm{B}$ decreased in samples with prevalent isomer B. Iothalamic acid was also stable in unbuffered samples.

\section{Application}

The analytical method described above was used to determine simultaneously both epimers of cefotetan and iothalamic acid in plasma and urine after intravenous injection of $1 \mathrm{~g}$ of cefotetan and $20 \mathrm{ml}$ of Conray 70 (containing $13.2 \mathrm{~g}$ of inthalamis arid) for nharmarnkinetir studies. Iothalamic acid is nearly 


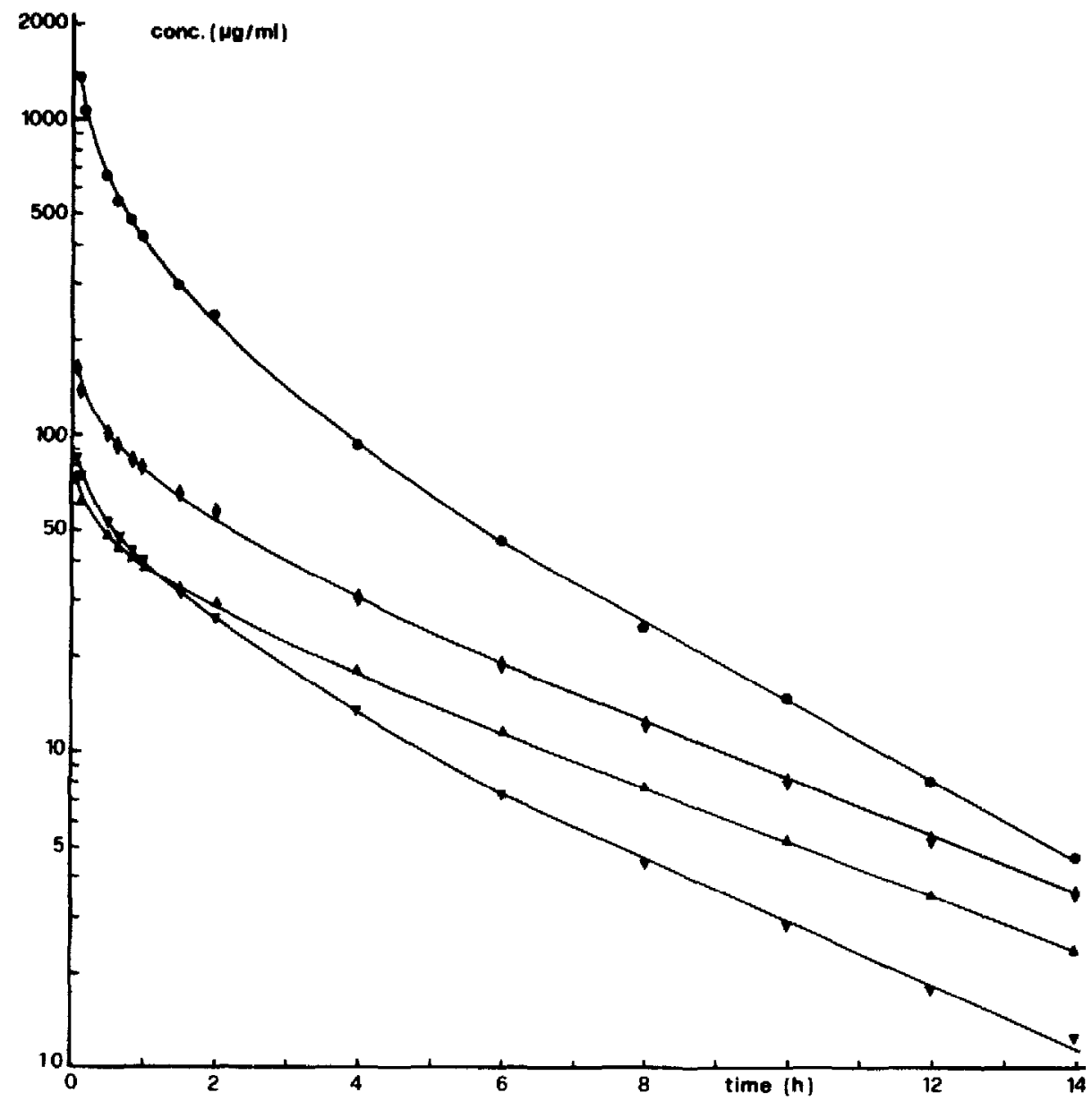

Fig. 4. Mean plasma concentrations of cefotetan (CTN, epimers $A$ and $B$ ) and iothalamic acid (ITS) after simultaneous intravenous injection of $1 \mathrm{~g}$ of cefotetan and $20 \mathrm{ml}$ of Conray 70 (corresponding to $13.2 \mathrm{~g}$ of iothalamic acid) to 12 healthy volunteers. (•), ITS; $(\bullet)$, CTN (A+B); (4), CTN-A; ( $)$, CTN-B.

exclusively eliminated through the kidney by glomerular filtration and served in this study as marker for the function of the kidney [11]. A detailed report will be published elsewhere [12]. In Fig. 4 the mean plasma concentrations of cefotetan obtained from twelve healthy volunteers are shown. As can be seen, the time-concentration curve of isomer $A$ is flatter. The terminal half-life was about $3 \mathrm{~h}$ for isomer $\mathrm{B}$ and $4 \mathrm{~h}$ for isomer $\mathrm{A}$, respectively. These data are in agreement with average half-lives of cefotetan found by others [1-4].

Immediately after cessation of the injection the ratio A/B was 40:60 and the reversed after $12 \mathrm{~h}$. The observed isomerisation in proteinaceous solutions was confirmed in vitro by incubation of cefotetan in phosphate buffer and $7 \%$ bovine serum albumin (BSA) at $\mathrm{pH}$ 7.4. As can be seen in Fig. 5, within $18 \mathrm{~h}$ the ratio shifted nearly to 50:50 in buffer, whereas in BSA solution the resulting ratio (70:30) was similar to that in plasma of volunteers. 


\section{DISCUSSION}

Beside the microbiological assay, HPLC has been established as a standard method to determine cephalosporins in biological matrices. Because of its precision, high linear range and possibility to detect and assay active metabolites quantitatively, as in the case of the 3-acetoxycephalosporins [7, 13], HPLC is the preferred method for pharmacokinetic studies. In addition, after simultaneous application of different antibiotics, separation and quantitation of the various compounds can be achieved.

In the present paper a different pharmacokinetic behaviour of each epimer of cefotetan has been demonstrated. The reason for this effect is probably a higher ratio of protein binding of epimer A, which can be assumed from the observed lower recovery after deproteinisation with acetonitrile, and the isomerisation in BSA solution leading to another ratio of the epimers than in buffer. On the other hand, lower stability of epimer B could contribute to this effect too, because in BSA solution degradation of cefotetan is enhanced with respect to the buffer (Fig. 5). Similar results were obtained from work with moxalactam. Commercially available moxalactam preparations are also mixtures of two epimers with slightly different protein-binding ratios, biological half-lives and antimicrobial activities [14-19]. As both epimers of cefotetan have a similar antibacterial activity [20], probably no clinical consequences will result from the finding of different serum half-lives for the isomers. Whether accumulation of isomer A will occur in plasma or other body fluids after multiple doses of cefotetan seems questionable, since both epimers are presumably in equilibrium with each other. The analytical method described in the present paper could clarify this problem during further clinical trials.

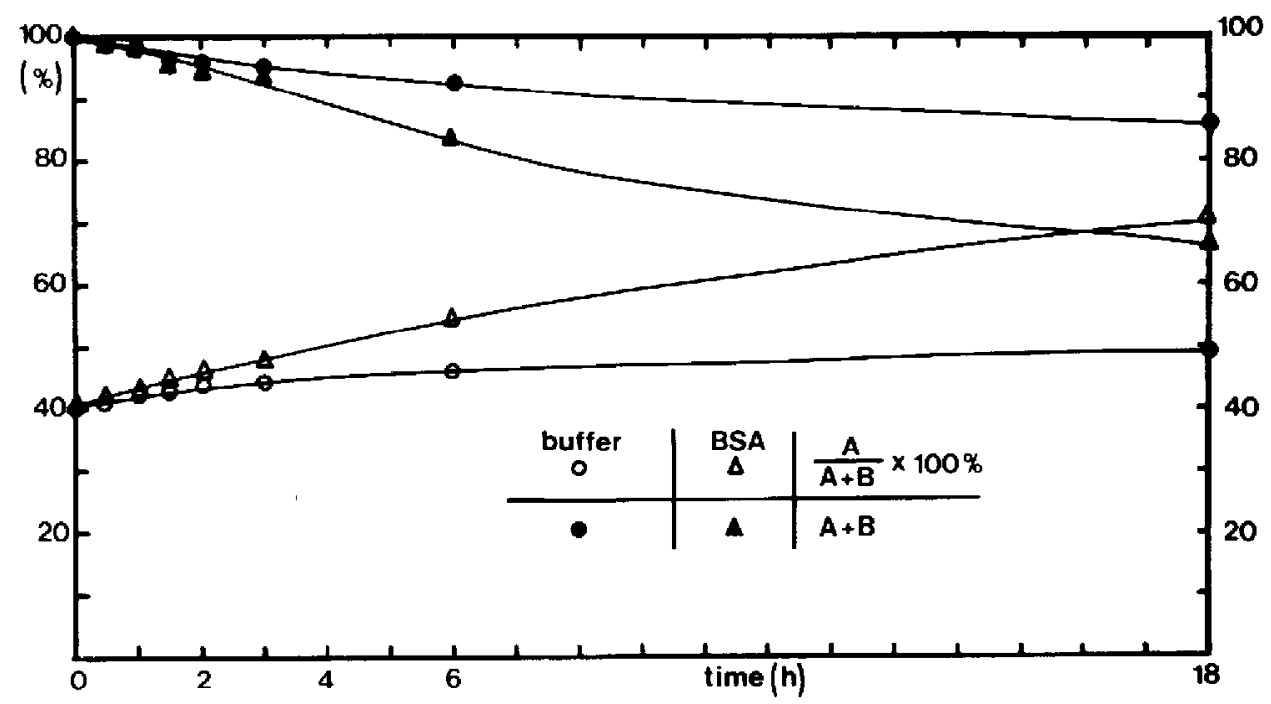

Fig. 5. Degradation of cefotetan (mixture of epimers $\mathrm{A}$ and $\mathrm{B}$ ) at $37^{\circ} \mathrm{C}, \mathrm{pH}=7.4$, in $0.1 \mathrm{M}$ sodium phosphate buffer $(\circ, \bullet)$ and $7 \%$ bovine serum albumin (BSA) solution $(\triangle, \bullet)$. Increase in fraction of epimer $A$. 


\section{ACKNOWLEDGEMENT}

We are greatly indebted to Ms. E. Scheidler for her skilful assistance with the experimental HPLC work.

\section{REFERENCES}

1 K. Nagakawa, M. Koyama, A. Tachibana, M. Komiya, M. Kikuchi and K. Yano, Antimicrob. Agents Chemother., 22 (1982) 935.

2 M. Ohkowa, S. Hirano, S. Tokunaga, I. Motoi, R. Shoda, A. Ikeda, T. Sugata, M. Sawaki, M. Shimamura, A. Okasho and K. Kuroda, Antimicrob. Agents Chemother., 23 (1983) 31.

3 R.A. Yates, H.K. Adam, R.J. Donnelly and H.L. Houghton, E.A. Charlesworth and E.A. Laws, J. Antimicrob. Chemother., 11 (Suppl. A) (1983) 185.

4 H.K. Adam, H.L. Houghton, R.A. Yates, J. Young and R.J. Donnelly, J. Antimicrob. Chemother., 11 (Suppl. A) (1983) 193.

5 G.R. Grannemann and L.T. Sennello, J. Chromatogr., 229 (1982) 149.

6 A.M. Brisson and J.B. Fourtillan, J. Chromatogr., 223 (1981) 393.

7 D. Dell, J. Chamberlain and F. Coppin, J. Chromatogr., 226 (1981) 431.

8 J.D'Souza and R.J. Ogilvie, J. Chromatogr., 232 (1982) 212.

9 J.T. Rudrik and R.E. Bawdon, J. Liquid Chromatogr., 4 (1981) 1525

10 S.R. Gambino, Clin. Chem., 28 (1982) 393.

11 E.M. Sigman, C.M. Elwood and F. Knox, J. Nucl. Med., 7 (1965) 60.

12 K.G. Naber, in preparation.

13 F. Kees, E. Strehl, K. Seeger, G. Seidel, P. Dominiak and H. Grobecker, Arzneim.Forsch., 31 (1981) 362.

14 R. Wise, P.J. Wills and K.A. Bedford, Antimicrob. Agents Chemother., 20 (1981) 30.

15 R. Konaka, K. Kuruma, R. Nishimura, Y. Kimura and T. Yoshida, J. Chromatogr., 225 (1981) 169.

16 M.K. Aravind, J.N. Miceli and R.E. Kauffman, J. Chromatogr., 228 (1982) 418.

17 H. Yamada, T. Ichihashi, K. Hirano and H. Kinsohita, J. Pharm. Sci., 70 (1981) 113.

18 H. Yamada, T. Ichihashi, K. Hirano and H. Kinoshita, J. Pharm. Sci., 70 (1981) 112.

19 J.A. Ziemniak, D.A. Chiarmonte, D.J. Miner and J.J. Schentag, J. Pharm. Sci., 71 (1982) 399.

20 H.G. Walch, personal communication. 